\title{
Factors Influencing Purchase Intention of Halal Products in Pontianak City
}

\author{
Riadi Budiman \\ Department of Industrial Engineering, Faculty of Engineering, Universitas Tanjungpura, Pontianak \\ H. Hadari Nawawi Street, 78124 \\ e-mail:*riadi@untan.ac.id \\ *Correspondent Author \\ DOI: 10.5575/ijhar.v1i2.4440
}

\begin{abstract}
Halal certification is a halal recognition by MUI on a product that is important especially for Muslim consumers. The existence of a halal label on a product provides added value to businessmen while consumers getting a consumer guarantee. Based on The Republic of Indonesia Law No. 33 of 2014 regarding the guarantee of halal products, the provisions of halal products are based on ingredients and processing. This study focuses on the halal production process based on Islamic Shari'a. This study aimed to identify the factors influencing consumer interest in halal food products. The results showed that halal certification, halal awareness, food ingredients affect purchase intention. These three factors may become consideration for the producer to produce their product.
\end{abstract}

Keywords: halal, Pontianak towards a halal city.

\section{Introduction}

The city of Pontianak has the characteristics of a heterogeneous society consisting of 3 ethnic groups namely TIDAYU (Tionghoa, Dayak and Malay). Based on population statistics of West Kalimantan Province, the population of non-Muslims in West Kalimantan was recorded as $2 / 3$ of the Muslim population as many as $3,206,084$ people. The people of Pontianak City, in particular, have behaviors/habits to eat outside for habitual reasons or just want to try tasting new culinary delights.

According to data from the Central Statistics Agency (BPS) since 2015, in the city of Pontianak, the developments in the trade, hotel, and restaurant sectors continue. The types of culinary in Pontianak City are more diverse, which make competition in this business more creative. In terms of taste and aesthetics to the consumer's guarantee become the attention of business owners. Competition in terms of taste and aesthetics is the creativity demanded by each food business owners; however, the issue of consumer's guarantee is actually related to the halal certification in the products produced.

The Muslim community of Pontianak City, they should be careful in choosing the desired location/type of food they intend to eat as it is an obligation for a Muslim to eat halal food. The presence of a halal logo on the products issued by MUI makes it is easier and sure for Muslim communities in choosing halal products. The halal logo on products guarantees legal protection for Muslim consumers in Indonesia. This has been stated in Law No. 33 of 2014 related to the guarantee of halal products.

However, most IKMs have not yet got the halal certification on their products. Therefore, this study aimed to identify the factors influencing consumer interest in halal food products as well as provide knowledge on development strategies and increase business value by having a halal logo as an added-value product.

\section{Materials and Methods}

The blue ocean strategy is characterized by unexplored market space, demand creation, and very profitable growth opportunities. (Kim, 2005). The blue ocean strategy is a strategy that focuses on growing demand by creating new market spaces that have not been explored by competitors. In this case, the added value which becomes the main focus is the halal logo on the product. IKM products that have the MUI halal logo will become the main attraction to increase sales value. 
The tools that being used in Blue Ocean Strategy including a six paths framework, a strategy canvas and a value curve, three tiers of non-consumers, a four action framework, the Eliminate-Reduce-Raise-Create (ERRC) Grid and a blue ocean strategy series to identify the competition factors, so that the formulation of strategies for business development can be generated. This research facilitates business owners by providing knowledge about the importance of halal certification in products.

\section{a. Halal Certification}

The Halal certification in Indonesia is officially issued by the MUI. Products that have halal certification are products that have been passed the halal test and can be consumed by Muslims. Products that have been halal-certified are proved by the inclusion of a halal logo on the product packaging (www.halalmui.org).

\section{b. Purchase Intention}

Based on the Planned Behavior Theory which is used as a basis for measuring consumer buying intention, some researchers agree that intention is an indication to show individual beliefs to buy halal food products. For example, a Muslim consumer has the intention to buy halal food products which are displayed in the product arrangement.

\section{c. Object of Research}

The objects in this study were IKM/UKM in Pontianak City that were not halal-certified by MUI. This study used a quantitative approach. The survey method was chosen as the primary data source. The survey method focused on collecting the respondent's data. Data collection from the respondents was conducted using questionnaires. Primary data was obtained through interviews directly with the owner.

\section{d. Data Collection Methods}

This study was conducted from June to August 2018 in several samples of IKM/UKM in the City of Pontianak. The simple random sampling which was tested its validity and reliability was used to determine the samples. The methods of data collection used in this study were observation, interviews, discussions, and questionnaires.

\section{Result and Discussion \\ Results of 2 Variables Analysis}

The results of the descriptive analysis of the halal certification variables show in the table below:

Table 1. Variable Categorization of Halal Certification

\begin{tabular}{cccc}
\hline Category & $\begin{array}{c}\text { Internal } \\
\text { Score }\end{array}$ & Frequency & Percentage \\
\hline High & $\mathrm{x}>=63,988$ & 44 & $20,5 \%$ \\
\hline Moderate & $\begin{array}{c}52,161>\mathrm{x}>= \\
63,987\end{array}$ & 135 & $62,8 \%$ \\
\hline Low & $52,161>\mathrm{X}$ & 36 & $16,7 \%$ \\
\hline Total & & 215 & $100 \%$ \\
\hline
\end{tabular}

Based on the table, it can be concluded that some respondents only use halal certification to choose halal food. While the results of purchase intention variables analysis are as follows:

Table 2. Category of Purchase Intention Variables

\begin{tabular}{cccc}
\hline Category & Internal Score & Frequency & Percentage \\
\hline High & $\mathrm{X} \geq 34.068$ & 38 & $17,7 \%$ \\
Moderate & $28.741>\mathrm{X} \geq 34.068$ & 135 & $62,8 \%$ \\
Low & $28.741>\mathrm{X}$ & 42 & $19,5 \%$ \\
\hline \multicolumn{2}{c}{ Total } & 215 & $100,00 \%$ \\
\hline
\end{tabular}

The result of the analysis of purchase intention showed that out of 215 respondents, there were as many as 135 people $(62.8 \%)$ have moderate purchase intention. 42 people $(19.5 \%)$ were on the low category, and a total of 38 people $(17.7 \%)$ have high purchase intention. This is suggesting that some respondents have sufficient interest to buy halal food products.

\section{Hypothesis Testing}

In this study, it hypothesized that there is a positive effect of halal certification, halal awareness and food ingredients towards purchase intention. Multiple regression analysis was conducted using SPSS 20 to analyze the result.

Table 3. Results of Multiple Regression Analysis

\begin{tabular}{lcccc}
\hline Variable & Coeff. (B) & t- value & Sig. & Conclusion \\
\hline $\begin{array}{c}\text { Halal } \\
\text { Certification } \\
\quad \text { Halal }\end{array}$ & 0,106 & 3,654 & 0,000 & Significant \\
$\begin{array}{c}\text { Awareness } \\
\quad 0,251\end{array}$ & 3,994 & 0,000 & Significant \\
$\quad \begin{array}{l}\text { Food } \\
\text { Ingredients }\end{array}$ & 0,191 & 2,555 & 0,011 & Significant \\
\hline Constanta $=13,467$ & & & \\
\hline Adjusted R2 $=0,288$ & & & \\
\hline F Value $=29,835$ & & & \\
\hline Significance $=0,000$ & & & \\
\hline
\end{tabular}


The results showed that the fourth hypothesis, namely halal certification, halal awareness, and material composition, as well as the three variables jointly affecting purchase intention are statistically acceptable.

Table 4. Summary of hypothesis verification

\begin{tabular}{clc}
\hline No & \multicolumn{1}{c}{ Hypothesis } & Verification \\
\hline 1 & $\begin{array}{l}\text { Halal certification has a } \\
\text { positive and significant } \\
\text { effect on purchase } \\
\text { intention }\end{array}$ & Accepted \\
& $\begin{array}{l}\text { Halal awareness has a } \\
\text { positive and significant } \\
\text { effect on purchase } \\
\text { intention } \\
\text { food ingredients has a } \\
\text { positive and significant } \\
\text { effect on purchase } \\
\text { intention }\end{array}$ & Accepted \\
& $\begin{array}{l}\text { Halal certification, halal } \\
\text { awareness, food } \\
\text { ingredients have positive } \\
\text { and significant effect on } \\
\text { purchase intention }\end{array}$ & Accepted \\
\hline
\end{tabular}

\section{Conclusion}

Halal certification, halal awareness, food ingredients affect purchase intention by $28.8 \%$. While the remaining $71.2 \%$ is influenced by other factors that were not examined by the researcher. The result showed that all variables affect the purchase intention of consumers. it means that halal certification, halal awareness, and food ingredients may cause the consumer's buying intention high in halal food products.
The suggestion is the producer of the food product should consider the three factors namely halal certification, halal awareness, and food ingredients on the product as nowadays Muslims are consumers which become potential markets for halal food products.

\section{References}

Halal Majelis Ulama Indonesia Kalimantan Barat.

Kim, W. C. \& Marborgne, R. (2017). Blue Ocean Shift; Pergeseran Samudra Biru Melampaui Persaingan. Jakarta: PT. Gramedia.

Kim, W. C., Marborgne, R. (2015). Blue Ocean Strategy. Cetakan IV. Jakarta: PT. Serami Ilmu Semesta.

Kim, W. C., Marborgne, Re. (2016). Blue Ocean Strategy; Menciptakan Ruang Pasar Tanpa Pesaing dan Menjadikan Persaingan Tidak Lagi Relevan. Jakarta: Noura Books.

Kotler, Philip., Keller, Kevin Lane. (2007). Manajemen Pemasaran; edisi dua belas jilid 2. Indonesia. PT. Indeks. 